Member Values Over Time. A Study oft he Relationship Between Member Values, Age and Length of Membership

\title{
Peter Suter
}

studied social sciences with a focus on social work and social politics and worked as a research assistant at the institute of educational science at the University of Fribourg/CH. From autumn 2011 until fall 2017 Peter Suter was a PhD student and worked as a research assistant at the Institute for Research on Management of Associations, Foundations and Co-operatives (VMI) at the University of Fribourg/CH.

\section{Markus Gmür}

Is Professor of NPO Management at the Faculty of Economics and Social Sciences of the University of Fribourg/CH since 2008. He is research director of the Institute for Research on Management of Associations, Foundations and Co-operatives (VMI).

JEL

L3, L31, Z13 